\title{
Sin: Female Subjectivity in Novel Wattpad Indonesia
}

\author{
Roma Kyo Kae Saniro \\ \{romakyok@gmail.com\} \\ Postgraduate Program in Literature Studies, University of Indonesia, Jalan Margonda Raya, Pondok \\ Cina, Kecamatan Beiji, Kota Depok, West Java, Indonesia
}

\begin{abstract}
The purpose of this study is to reveal the subjectivity of the female protagonist in the novel Wattpad Indonesia, entitled Sin. Sin is a novel that was first published on March 24, 2016 with 57 story parts by an account called @ faradisme. This novel has been read 26.6 million times and voted 1.4 million times (data per November 1, 2020). In 2019, this novel has also been filmed with the same title on October 10, 2019 by Herwin Novianto. This study used a qualitative research method with a structural approach and deepened through Simon de Beauvouir's concept of existential feminism. The results of this study reveal that the novel narrative tries to negate the various views about women who are always second sex in patriarchal societies. The female character is able to show her subjectivity through the choices she makes.
\end{abstract}

Keywords: feminism, Sin, Simon de Beauvoir, subjectivity, Wattpad

\section{Introduction}

Novel Wattpad is a writing platform that can be said to have various enthusiasts. This platform was created by Canadians named Allen Lau and Ivan Yuen in 2006. According to research conducted by Vadde [1] , in 2016, Wattpad had more than 40 million members. In addition, according to Alexa Global Rank, Wattpad is in the rank of 660 for websites frequently visited by the public. Through the Web 2.0 Platform, Wattpad brings users into the sharing economy because everyone can access and share their own stories without spending money. In other words, Wattpad can be said to be a free novel that is available in fifty languages and the content format offered is very easy to read on a computer, cellphone or tablet.

According to Peltier-Davis [2], people spend more than 9 million minutes each month using Wattpad (both reading and writing works). In addition, Reid [3] says Wattpad has become a multiplatform entertainment, which attracts more than 45 million visitors every month. As expressed by Bidisha [4], Adsit [5], and Matrens [6] that the digitalization phenomenon cannot be separated between digital and conventional publishing. The work of Wattpad, which has a lot of readability, will be offered by conventional publishers and eventually the work will be printed conventionally. This is an advantage that a variety of cyber literature has on various free writing platforms.

The development of Wattpad started in the United States, United Kingdom, Canada, Philippines, Australia, Russia, United Arab Emirates and then followed in Indonesia. In Indonesia, Wattpad appeared with various beginner or indie writers whose names eventually became famous. However, there are also famous writers who deliberately wrote on Wattpad to raise their name again. This is as expressed by Sari [7] as follows. 
"Writers on Wattpad have the same goal, namely, to develop their writing skills, both fiction and nonfiction. Most of the writers on Wattpad are young, so their word processing and grammar skills still need a lot of improvement. However, professional writers can take advantage of Wattpad for self-actualization, publisher requests, and so on. With the variety of writings on Wattpad, the ability to develop creative writing is increasingly wide open. Innovation in ideas, genres, utilization of technology, and writer's message can be more developed. Apart from that, a direct connection as a response to writing uploaded on Wattpad is a special value for the author" (C-4).

The phenomenon of Wattpad in Indonesia can be seen from various works in various forms, one of which is the novel Sin which is also written by novice writers. This novel can be categorized as a romantic novel containing various stories of women. This woman's story contains the idea of women's freedom to choose in her life. Women as said by Beauvoir [8] are second-class creatures who seem to have no choice in life. Moreover, in the context of a patriarchal society. Women must obey the norms or rules that support their freedom. However, through this novel, women are presented as characters who have subjectivity in their lives.

Research using the Wattpad corpus has been conducted by several people. However, with a different approach. Yang [9] uses a gender approach and Hedrick [10] uses sex and gender in love and sex as a result of being patriarchal sexist. Meanwhile, Benzquen-Gautier [11] (with a corpus of 65 Wattpad stories with the theme of the Holocaust) uses a literary romance approach with the results of research that there is a relationship between history, fiction and writing that appears in Holocaust romances.

\section{Research Methods}

This study used a qualitative research method with a structural approach and deepened with Simon de Beauvoir's concept of existential feminism. To reveal the freedom of female characters as subjects in this study, this research can be done through several research steps. This research will be conducted in five stages, namely the data collection stage, the data selection stage, the discussion stage, and the conclusion stage. The data collection stage was carried out by collecting various Wattpad literary works that became popular or gained attention with the parameter of the number of readers in the millions and having a world of transmedia.

Furthermore, in the discussion stage, the researcher will discuss the subjectivity of female protagonists based on the portrayal of the protagonist in the narrative using Bal's narrative theory [12] through the characters in the text and describing the subjectivity of women through Beauvoir's theory of existentialist feminism. The last stage of this research is the stage of drawing conclusions to conclude the results of the analysis regarding the subjectivity of women in research.

The concept used is Simon de Beauvoir's existentialist feminism. The choice of this concept is motivated by a text that seeks to present a path of liberation for women from discrimination. According to Beauvoir [8], femininity and masculinity are interchangeable things, in contrast to the rigid natures of women and men. Agreeing with Beauvoir, Figes [13] also reinforces that femininity and masculinity are binary oppositions that focus on the body based on biological categories. 


\section{Results and Discussion}

Novel Sin, one of the novels that can be said to have a large total of readings was written by an account called @faradita [14]. This novel was first published on March 24, 2016 and has been read as many as 26.6 million and voted 1.4 million times. Due to the large number of readings, this novel finally received attention from publisher Kubusmedia and director Herwin Novianto so that this novel was born into a printed book and film with the same title. The protagonist in this novel, Metta, will be the focal point of the research. The description of the female subjectivity is obtained through the depiction of the Metta character in the narrative and the subjectivity of the Metta character as a woman.

\subsection{Metta Character Depiction in Narrative Narrator in Novel Sin}

Analysis of the narrator's position was carried out before analysing the depiction of the Metta character. The position of the narrator is based on the way the narrator delivers the narrative. The direct depiction of Metta can be seen from the narrator's narrative. The narrator's narrative provides an overview of Metta's character which is conveyed directly by the narrator. Then, the depiction of Metta is indirectly carried out through the telling of other characters in the story. Character selection is based on the character's closeness to life and intense interaction with Metta.

The narrator in Sin's novel is a knowledgeable narrator or external narrator. This all-knowing narrator is outside the narrative and tries to tell the various characters, both the protagonist and other characters. The character of Metta in the story is presented by the narrator as a woman who is not afraid to defend the truth. This can be seen through the following excerpt.

"Saya gak salah, Bu." Sela Metta tidak terima. "Dia cowok berengsek yang hampir memerkosa saya. Kalau ibu ngomongin tindak kriminal, dia itu orangnya."

"Tapi saya bicara kebenaran. Saya tidak akan mematahkan hidung Rio jika dia tidak memulai mencari gara-gara. Saya hanya memberikannya pelajaran.” Metta menyilangkan tangan di depan dada. Kalimatnya keluar secara datar tanpa emosi. Tidak nampak sedikit pun penyesalan karena telah memukuli anak laki-laki (Menutupi Kegelisahan).

The narrator presents the character Metta who dares to defend herself as a woman for her treatment of beating men for wanting to rape her. Through these quotes, the narrator seems to know the actions and events of the Metta character. As a well-versed narrator, the narrator also reveals the thoughts of Metta's character about her choice as a woman.

Tidak ada yang bisa membaca hari esok, bahkan satu detik dari sekarang. Itulah kenapa kita dikenal bukan saja sebagai pemimpin, tapi juga pendosa. Kita semua terancam akan melakukan kekeliruan. Tapi, hal baiknya kita adalah kita masih diberikan kesempatan. Diberikan waktu untuk mencoba kembali. Metta pun menyadari, sebuah kesempatan bukanlah untuk menyakiti kembali, tapi untuk menyadarkan kita agar memperbaiki diri. Jika kesalahan adalah pekerjaan tertunda yang patut diselesaikan.

Pada akhirnya, kesempatan kedua akan selalu ada, bahkan bagi mereka yang berdosa. (Invalidite, Extra Chapter)

The quote shows that the narrator seems to know the thoughts of the Metta character on everything that has been going on throughout her life. The Metta character thinks that she can correct herself from the previous mistakes. As a sinner, the Metta character deserves a second chance and improves herself. 


\section{Metta as a Brave Woman}

The direct depiction of Metta can be seen through the narrator's narrative. Metta is shown as a woman who has the courage to fight the injustices that have been done by a male character (Rio) to her. This is reflected in the following quotations.

"Saya gak salah, Bu." Sela Metta tidak terima. "Dia cowok berengsek yang hampir memerkosa saya. Kalau ibu ngomongin tindak kriminal, dia itu orangnya."

"Jaga bahasa kamu saat bicara sama saya!"

"Tapi, saya bicara kebenaran. Saya tidak akan mematahkan hidung Rio jika dia tidak memulai mencari gara-gara. Saya hanya memberinya pelajaran. "Metta menyilangkan tangan di depan dada. Kalimatnya keluar secara datar tanpa emosi. Tidak Nampak sedikit pun penyesalan karena telah memukuli anak laki-laki.

Metta tahu, perkataan apa pun yang ia keluarkan tidak akan membuatnya terbebas dari hukuman. Ia justru sedang menegakkan keadilan di sini. Masih untung dia tadi mengurungkan niat untuk mematahkan salah satu kaki Rio (Menutupi Kegelisahan).

Metta, who can be said to be popular at school, is the center of attention, especially from her male friends. This made Rio turn metta back into his girlfriend even in a bad way. This resulted in Rio giving a drink which had been mixed with stimulants in order to rape Metta. However, in the end his lecherous intention was cancelled. When they meet again at school, Rio still asks to have a love affair with Metta and Metta who is annoyed by giving lessons by punching Rio in the face. This courage was done by Metta to defend herself. Metta was not afraid to refuse Rio's request to become her lover with words. Even with physical courage that women usually don't do without thinking about the consequences it will receive. Metta just wants to protect herself.

In addition, Metta's courage to oppose the words of her teacher who even blamed Metta for her actions. Metta tries to uphold the justice she should get as a woman through the path she wants. This shows Metta's courage to break society's stipulations that women are usually seen as subtle-beings and behave subtly and accept any conditions. Metta can take over control in determining his own life path.

In addition, Metta also dared to fight other women who insulted her as a woman without a clear origin. The discomfort of this insult made Metta dare to fight back. Metta is a picture of a woman who is able to defend herself.

\section{Metta as an independent woman}

Independent in this section means that Metta can live alone without direct supervision or escort from others. The narrator also presents Metta as an independent woman who prefers to look after herself in the public sphere. This can be seen through the following excerpt.

"Atas perintah langsung dari seseorang yang bertanggung jawab penuh atas Nona, dengan ini Nona dilarang keras untuk berbuat hal yang berbahaya dan merugikan lagi. Seperti berkelahi atau memancing kericuhan..."

"Karena hal-hal tersebut, mulai sekarang akan ada pengawal yang mengikuti Nona ke mana pun."

Metta membulatkan mata. Setelah mengurungnya, lalu sekarang mereka memberi Metta anjing penguntit. Ini bahkan jauh lebih buruk daripada disebut sebagai tahanan.

Dan seperti sebelumnya, keputusan ini tidak bisa ditolak."

Gue bisa nolak! Teriaknya. "Kalo dia, atau siapa pun itu bos kalian mau ngelarang gue, bilang sama dia untuk lakuin itu sendiri. hadapin gue. Jangan cuma berani mengirim pesuruhnya untuk datang!" 
Metta is described as a woman who doesn't like to be guarded by bodyguards. Since childhood, Metta has lived alone without anyone else even though there is financial support from adoptive parents whom she has never met. Metta's loneliness in living life makes Metta able to be independent by taking care of herself without the presence of anyone who can guide her. The presence of bodyguards in the narrative is when Metta is deemed able to do something unwanted. However, this was attempted by Metta. Women are not bound by society's rules that women are always protected. Metta in the narrative is shown as a strong woman to take care of herself.

The guardianship applied by the adoptive parents, as if women had to be guarded so as not to do anything detrimental, was a limitation on women's freedom. However, the narrator tries to describe that women are able to fight against this. Metta is able to escape from the guard imposed on her to do whatever prohibits her.

Metta is also described as a woman who can achieve her desires through her modeling profession. This can be seen through the following excerpt.

Pemotretan berjalan lancar. Tidak perlu waktu lama untuk mendapatkan foto yang bagus dari seorang Ametta Rinjani. Sang fotografer bahkan percaya, cukup Metta berdiam diri saja, itu sudah bisa dijadikan sampul terdepan majalah (Dipaksa Peduli).

The model profession that has been carried out since school is his choice, not coercion from others. Metta does it with pleasure and not for the purpose of earning money, but for inner satisfaction as a model.

\subsection{Subjectivity of Metta as a Woman}

The subjectivity of women can be seen from three things in the form of women and the public space and women, sexuality and body.

\section{Women and Public Spaces}

In Sin's novel, women are shown to have a brave attitude. Metta's courage in upholding justice for the harassment that was done by men to her. Women are always muted when they get harassed by men. Women are always the victims and are blamed for harassment. Society blames women for not obeying immoral norms regarding the use of clothes etc. which is considered indulging his body sexiness. Metta in the text tries to fight against male domination which is always considered right by others.

"Saya harap kamu mengerti akan apa yang sudah kamu lakukan. Ini bukan perkara kamu salah dan mendapat hukuman lalu selesai. Kamu sudah berlaku kriminal."

Saya gak salah, Bu. Sela Metta tidak terima. "Dia cowok brengsek yang hampir memerkosa saya. Kalau Ibu ngomongin tindak kriminal, dia itu orangnya."

"Jaga bahasa kamu saat bicara sama saya!"

"Tapi, saya bicara kebenaran. Saya tidak akan mematahkan hidung Rio jika dia tidak memulai mencari gara-gara. Saya hanya memberinya pelajaran. "Metta menyilangkan tangan di depan dada. Kalimatnya keluar secara datar tanpa emosi. Tidak nampak pun penyesalan karena telah memukuli anak laki-laki. ("Menutupi Kegelisahan”)

However, when Metta hit Rio's face, she was called a counselling teacher. However, subordination also arises from the distrust of her counselling teachers who are fellow women. The injustice he received caused Metta to speak up. However, the views of society always corner women. Women are the ones who should be considered guilty if someone wants to rape or sexually abuse her. The stereotype of women as flirtatious or naughty creatures who wear sexy 
clothes or indulge in their bodies is one of the reasons patriarchal society perpetuates these violations.

Women's voices are considered useless because of these stereotypes. Truth seems unnoticed when people see that the subject speaking is a woman. Women are always considered as second-class creatures. Diction But, I speak the truth to show Metta's choice to voice his rights. Women in the patriarchal society prefer to remain silent about all the injustices that are obtained or seek a safe position. What's more, if women have to deal with men. However, Metta is still blamed by her BK teacher who is a woman. This feeling of distrust also arose due to Metta's seemingly rude attitude. Women are able to protect themselves and their dignity. Metta does things for logical reasons. Women have the choice to be silent or speak up. Metta is a representation of women who are not afraid to fight against men.

The novel also positions women as independent creatures and can take care of themselves. This is very different from the construction of society in that women must be protected because they are weak, especially women who are still in school. Women who are still in school are considered to be under the supervision of their parents or adults because they are considered unable to protect themselves and face unexpected lives in the public domain. However, the text tries to break this social construction. Women are depicted as figures who choose to be able to look after themselves without having to hire bodyguards to their guardians.

Women are able to look after themselves in the public sphere. Women are considered as beings with weak bodies which can be seen as constructs in a patriarchal system. The rules must always be guarded by hired guards, rejected outright by the figures. Bodyguard diction means someone who is in charge of protecting someone because they are considered to have weaknesses, so they deserve protection. Women are considered unable to protect themselves from various threats in the public sphere. Society has a stereotype that women are considered as something very vulnerable because if women have experienced sexual cases, women will be considered damaged and destroyed with marks. In contrast to this, men are considered capable of taking care of themselves and will not leave marks like women.

However, the text narrative tries to break this assumption. Women have their subjectivity by choosing to live without being escorted. This is reflected in the diction, "If he, or whoever is your boss, wants to block me, tell him to do it himself. face me. Don't just dare to send messengers to come!". From these quotes it shows that women are able to fight the support made by others for their lives. The woman further tries to fight back to challenge her life support.

\section{Women, Sexuality, and Body}

The narrator in the text shows that women are able to free themselves from desiring sexuality to the man she likes. Women are considered as creatures supported by various norms so that women who express their sexual desires are considered as bad women. However, the text narrative tries to describe Metta as having freedom over sexuality and the body she has. In the end, Metta expressed her desire for Raga who at first thought he was her brother.

Kemudian Metta memajukan wajah dan menyentuh bibir Raga dengan bibirnya. Menempel beberapa saat sebelum ia mengulum bibir bawah Raga lembut, lalu menggigitnya. Sontak saja hal itu menimbulkan pekikan dari Raga karena rupanya Metta tidak main-main (Lebih Bersama).

Despite the fact, Carnes shows society today we live in a culture that considers sex as a positive thing [15]. However, traditional sexuality values tend to still glorify morality and consider women who are related to or within the circle of sexual issues as close to sin.

Then, for the love Metta has, Metta decided to keep her relationship with Raga, her brother. The family propaganda contained in the Sin text is that it is not permissible for fellow family to 
marry. The character of Raga's parents through her father clearly does not allow his son to have a love relationship with Metta who is considered to be her brother. The old man seemed to remind her that the relationship that the Raga character was going through was wrong and had to be addressed immediately.

This conflict regarding inbreeding can be related to the view of the concept of incest in society. According to Read [16], prohibiting incest in society is considered a taboo. In addition, in his writings he said that sociologists in the 19th century tried to show that the reason for the prohibition of incest was to avoid role confusion. However, in his book, read tries to argue about the incest taboo. Raga and Metta's opposition to having a love affair did not make the two characters immediately give up. The Metta character initially intended to withdraw through the propaganda that Raga's father said. However, the love that women have does not make women have to be supported by the community construction prison. Metta is back in a relationship with Raga and maintains her love.

The maintenance of inbreeding done by women shows that women can choose freedom in their love relationships. Women are able to defend their desires even though it is very contrary to the norms that exist in society. The female character who initially accepts the concept of incest which is prohibited by her family is transformed into a woman who has the freedom to live life and defines herself as a woman. Self-identification carried out by the Me.

\section{Conclusion}

Sin is one of Wattpad's novels with a million readings. This number led to the novel being printed and filmed. In fact, this novel contains the subjectivity shown by a female protagonist named Metta. Subjectivity is obtained through the narrator in Sin's narrative using an external narrator. Then, the narrator's analysis resulted in a depiction of Metta's character as a brave and independent woman. This formulation possessed by Metta is the direction for Metta's subjectivity in her life. Metta as a woman is able to choose and determine her own path in life.

Therefore, the narrative in Sin's novel tries to break society's stereotypes about women who become second sex. Women have choices in life so that they can determine their own life. This research can be said to be far from perfect. The researcher hopes that there will be further research on the corpus or approach in this research. Hopefully this research can contribute to Indonesian literature, especially cyber literature.

\section{References}

[1] A. Vadde, "Amateur creativity: Contemporary literature and the digital publishing scene," New Lit. Hist., vol. 48, no. 1, pp. 27-51, 2017, doi: 10.1353/nlh.2017.0001.

[2] C. A. Peltier-Davis, "The Cybrarian's Web 2: An A-Z Guide to Free Social Media Tools, Apps, and Other Resources," J. Web Librariansh., vol. 11, no. 3-4, pp. 265-266, 2017, doi: 10.1080/19322909.2017.1376573.

[3] C. Reid, "How Wattpad Became a Multiplatform Entertainment Venue," Publ. Wkly., vol. 263, pp. 2-4, 2016, [Online]. Available: http://www.publishersweekly.com/pw/by-topic/digital/content-ande-books/article/72190-how-wattpad-became-a-multiplatform-entertainment-venue.html.

[4] Bidisha, "The literary cultures of the future," Wasafiri, vol. 29, no. 3, pp. 48-51, 2014, doi: 10.1080/02690055.2014.918332.

[5] K. Bradley, "Composition, Creative Writing Studies, and the Digital Humanities," Compos. Creat. Writ. Stud. Digit. Humanit., no. 6, pp. 1-4, 2016, doi: 10.5040/9781350001091. 
[6] M. Matrens, Publiser, Readers, and Digital Engagement. UK: Palgrave Macmillan, 2016.

[7] D. P. Sari, "Pengembangan menulis kreatif melalui Wattpad," Simp. Nas. Ilmu Pengetah. dan Teknol., pp. $\quad$ C1-C2, 2017, [Online]. Available: http://seminar.bsi.ac.id/simnasiptek/index.php/simnasiptek-2017/article/view/163/163.

[8] Simone de Beauvoir, The Second Sex. New York: Vintage Books, 2011.

[9] Y. Tang, "Between Fantasy and Reality: Time-Travel Romance and Media Fandom in Chinese Cyberspace," 2014.

[10] A. Hedrick, "One Direction Real Person Fiction on Wattpad.com: A Textual Analysis of Sex and Romance," vol. 21.

[11] S. Benzaquen-Gautier, "Romancing the Camp: Genres of Holocaust Memory on the Story-Sharing Website Wattpad," Dapim Stud. Holocaust, vol. 32, no. 2, pp. 75-92, 2018, doi: 10.1080/23256249.2018.1458773.

[12] M. Bal, Narratology: Introduction to the Theory of Narrative (Christine ban Boheemen, Translator). Taronto: University of Toronto Press, 1997.

[13] E. Figes, Patriarchal Attitudes. London: Macmillan Education, 1986.

[14] Faradita, "Sin," 2016. https://www.wattpad.com/story/75602829-sin-completed.

[15] P. J. Carnes, Sexual Anorexia: Overcalming Sexual Self Hatred. Minnesota: Hazelden Publishing, 1997.

[16] D. W. Read, "Incest Taboos and Kinship: A Biological or a Cultural Story?," Rev. Anthropol., vol. 43, no. 2, pp. 150-175, 2014, doi: 10.1080/00938157.2014.903151. 